\title{
Methane chemistry in a nutshell - the new submodels CH4 (v1.0) and TRSYNC (v1.0) in MESSy (v2.54.0)
}

\author{
Franziska Winterstein and Patrick Jöckel
}

Deutsches Zentrum für Luft- und Raumfahrt (DLR), Institut für Physik der Atmosphäre, Oberpfaffenhofen, Germany

Correspondence: Franziska Winterstein (franziska.winterstein@dlr.de)

Received: 15 May 2020 - Discussion started: 26 June 2020

Revised: 5 November 2020 - Accepted: 30 November 2020 - Published: 2 February 2021

\begin{abstract}
Climate projections including chemical feedbacks rely on state-of-the-art chemistry-climate models (CCMs). Of particular importance is the role of methane $\left(\mathrm{CH}_{4}\right)$ for the budget of stratospheric water vapour (SWV), which has an important climate impact. However, simulations with CCMs are, due to the large number of involved chemical species, computationally demanding, which limits the simulation of sensitivity studies.
\end{abstract}

To allow for sensitivity studies and ensemble simulations with a reduced demand for computational resources, we introduce a simplified approach to simulate the core of methane chemistry in form of the new Modular Earth Submodel System (MESSy) submodel CH4. It involves an atmospheric chemistry mechanism reduced to the sink reactions of $\mathrm{CH}_{4}$ with predefined fields of the hydroxyl radical $(\mathrm{OH})$, excited oxygen $\left(\mathrm{O}\left({ }^{1} \mathrm{D}\right)\right)$, and chlorine $(\mathrm{Cl})$, as well as photolysis and the reaction products limited to water vapour $\left(\mathrm{H}_{2} \mathrm{O}\right)$. This chemical production of $\mathrm{H}_{2} \mathrm{O}$ is optionally fed back onto the specific humidity $(q)$ of the connected general circulation model (GCM), to account for the impact onto SWV and its effect on radiation and stratospheric dynamics.

The submodel $\mathrm{CH} 4$ is further capable of simulating the four most prevalent $\mathrm{CH}_{4}$ isotopologues for carbon and hydrogen $\left(\mathrm{CH}_{4}\right.$ and $\mathrm{CH}_{3} \mathrm{D}$, as well as ${ }^{12} \mathrm{CH}_{4}$ and $\left.{ }^{13} \mathrm{CH}_{4}\right)$. Furthermore, the production of deuterated water vapour (HDO) is, similar to the production of $\mathrm{H}_{2} \mathrm{O}$ in the $\mathrm{CH}_{4}$ oxidation, optionally passed back to the isotopological hydrological cycle simulated by the submodel H2OISO, using the newly developed auxiliary submodel TRSYNC. Moreover, the simulation of a user-defined number of diagnostic $\mathrm{CH}_{4}$ age and emission classes is possible, the output of which can be used for offline inverse optimization techniques.
The presented approach combines the most important chemical hydrological feedback including the isotopic signatures with the advantages concerning the computational simplicity of a GCM, in comparison to a full-featured CCM.

\section{Introduction}

It is beyond question that methane $\left(\mathrm{CH}_{4}\right)$ is a strong greenhouse gas (GHG), with an estimated global warming potential (GWP) of 34 times that of carbon dioxide $\left(\mathrm{CO}_{2}\right)$ on a 100-year horizon (IPCC, 2013). Therefore, most general circulation models (GCMs) include the effect of the radiative forcing of $\mathrm{CH}_{4}$. However, the effect of $\mathrm{CH}_{4}$ is underrepresented by only using its direct radiative impact and not accounting for the water vapour $\left(\mathrm{H}_{2} \mathrm{O}\right)$ produced by the oxidation of $\mathrm{CH}_{4}$ due to a set-up without chemistry. Especially in the stratosphere, this additional $\mathrm{H}_{2} \mathrm{O}$ (stratospheric water vapour, SWV) influences, among other factors, the radiative forcing, stratospheric temperature, and ozone $\left(\mathrm{O}_{3}\right)$ chemistry (Stenke and Grewe, 2005; Tian et al., 2009; Solomon et al., 2010; Revell et al., 2012; Winterstein et al., 2019). The inclusion of production of $\mathrm{H}_{2} \mathrm{O}$ by $\mathrm{CH}_{4}$ requires a chemical mechanism as provided by chemistry-climate models (CCMs). Current state-of-the-art CCMs include a vast amount of chemical species and reactions. By extending the chemical mechanisms, it is intended to achieve an increase in accuracy of the atmospheric chemistry representation. At the same time, however, the computational demands increase. Although available computational power increases at a certain rate, the availability and capacity of high-performance computers is a limiting factor for sensitivity studies in climate projection simulations with CCMs. 
It is hence advisable to recognize both of the main effects of $\mathrm{CH}_{4}$, namely its radiative forcing and its impact on $\mathrm{SWV}$, while at the same time keeping computational demands low. Therefore, our approach to simulate $\mathrm{CH}_{4}$ includes both effects and is able to use predefined reaction partners of $\mathrm{CH}_{4}$, which reduces computational cost to a minimum.

An early version of the simplified $\mathrm{CH}_{4}$ chemistry submodel (CH4) has been described by Eichinger et al. (2015a). The present version has been updated and extended by the additional features for simulating age and emission classes and isotopologues.

Section 1.1 and 1.2 introduce the sources and sinks of $\mathrm{CH}_{4}$ and $\mathrm{CH}_{4}$ isotopologues and their fractionation effects, respectively. In Sect. 2, we briefly present the Modular Earth Submodel System and describe the concept of the CH4 submodel in Sect. 3. Two additional options of the $\mathrm{CH} 4$ submodel are explained in the subsequent Sect. 3.1 and 3.2. The coupling to the hydrological cycle with the submodel TRSYNC is introduced in Sect. 4. We show three example applications using the newly presented submodels in Sect. 5 and end with a short summary. Parts of the paper are based on the PhD thesis of the first author (Frank, 2018).

\subsection{Sources and sinks of $\mathrm{CH}_{4}$}

Methane is a GHG emitted by both natural and anthropogenic sources at the Earth's surface. There are basically no known chemical sources of $\mathrm{CH}_{4}$ in the free atmosphere.

In CCMs usually predefined lower boundary conditions instead of emission fluxes are used to describe atmospheric $\mathrm{CH}_{4}$. This approach is mainly employed due to two major problems. (1) The lifetime of $\mathrm{CH}_{4}$ is on an order of magnitude of 10 years, but its exact value is still unknown and subject to uncertainties. However, $\mathrm{CH}_{4}$ is an important precursor of the $\mathrm{O}_{x}-\mathrm{HO}_{x}$ chemistry in CCMs. For this reason, in most CCM set-ups $\mathrm{CH}_{4}$ is prescribed at the lower model boundary to achieve a realistic $\mathrm{CH}_{4}$ burden independent of the simulated lifetime. (2) Despite large ongoing efforts, current emission inventories are still subject to large uncertainties, as top-down and bottom-up inventories differ significantly (e.g. EDGAR or Saunois et al., 2016). This mismatch indicates the dilemma that there are a lot of open questions with respect to both the magnitude of sources and the sinks of $\mathrm{CH}_{4}$.

Methane is removed from the atmosphere mainly by three photochemical reactions:

$$
\begin{aligned}
& \mathrm{CH}_{4}+\mathrm{OH} \stackrel{k_{\mathrm{CH}_{4}+\mathrm{OH}}}{\rightarrow} \mathrm{CH}_{3}+\mathrm{H}_{2} \mathrm{O}, \\
& \mathrm{CH}_{4}+\mathrm{O}\left({ }^{1} \mathrm{D}\right) \stackrel{\left.k_{\mathrm{CH}_{4}+\mathrm{O}(1} \mathrm{D}\right)}{\rightarrow} \text { products, } \\
& \mathrm{CH}_{4}+\mathrm{Cl} \stackrel{k_{\mathrm{CH}_{4}+\mathrm{Cl}}}{\rightarrow} \mathrm{CH}_{3}+\mathrm{HCl},
\end{aligned}
$$

and is also depleted by photolysis:

$\mathrm{CH}_{4}+h v \stackrel{j_{\mathrm{CH}_{4}+h v}}{\rightarrow}$ products, with Reactions (R1)-(R3) taken from Sander et al. (2011) and Reaction (R4) taken from Sander et al. (2014).

About $92 \%$ of the atmospheric $\mathrm{CH}_{4}$ removal happens in the troposphere. The largest part is thereby the reaction with the hydroxyl radical $(\mathrm{OH})(>90 \%$ of the tropospheric sink), while the rest is attributed to the reaction with chlorine $(\mathrm{Cl})$ in the marine boundary layer (MBL, Kirschke et al., 2013). About $8 \%$ of $\mathrm{CH}_{4}$ is depleted in the stratosphere by the reactions with $\mathrm{OH}$, excited oxygen $\left(\mathrm{O}\left({ }^{1} \mathrm{D}\right)\right)$, and $\mathrm{Cl}$ and through photolysis (IPCC, 2013).

Another sink of $\mathrm{CH}_{4}$ is the so-called soil loss at the Earth's surface. $\mathrm{CH}_{4}$ is either depleted by $\mathrm{CH}_{4}$-consuming bacteria (methanotrophs) or it is removed from the air by diffusive transport into the soil, which is mostly influenced by soil water content (King, 1997). Globally, the soil loss accounts for approximately $4 \%$ of the total $\mathrm{CH}_{4} \operatorname{sink}$ (IPCC, 2013).

\subsection{Isotopologues of $\mathrm{CH}_{4}$}

A powerful and common method in the investigation of the $\mathrm{CH}_{4}$ budget is the study of $\mathrm{CH}_{4}$ isotopologues. Production and removal of $\mathrm{CH}_{4}$ both cause fractionation effects, which lead to distinct isotopological signals in the atmosphere. These isotopic signatures potentially provide additional insights into the role of specific $\mathrm{CH}_{4}$ sources and depleting reactions and are already widely used in the context of $\mathrm{CH}_{4}$ (Hein et al., 1997; Fletcher et al., 2004; Monteil et al., 2011; Rigby et al., 2012; Nisbet et al., 2016; Schaefer et al., 2016).

Fundamentally, the stable isotopologues of $\mathrm{CH}_{4}$ form with respect to the most abundant stable isotopes of hydrogen and carbon. The stable isotopes of hydrogen are ${ }^{1} \mathrm{H}$ and ${ }^{2} \mathrm{H}$ (deuterium, D), and for carbon the stable isotopes are carbon-12 $\left({ }^{12} \mathrm{C}\right)$ and carbon- $13\left({ }^{13} \mathrm{C}\right)$. This results in the first-order stable isotopologues ${ }^{12} \mathrm{CH}_{4},{ }^{13} \mathrm{CH}_{4}$, and $\mathrm{CH}_{3} \mathrm{D}$. The corresponding sink reactions are shown in the Supplement (Sect. S1). The relative abundances of higher substituted and mixed isotopologues (e.g. $\mathrm{CH}_{2} \mathrm{D}_{2}$ or ${ }^{13} \mathrm{CH}_{3} \mathrm{D}$ ) are less than $0.0007 \%$ (compared to $0.0616 \%$ of $\mathrm{CH}_{3} \mathrm{D}$ ) (Stolper et al., 2014) and hence neglected.

The chemical fractionation is based on the fact that isotopologues of the same molecule have different rate coefficients; i.e. they react with different speed or probability. This difference in rate coefficients is described as the so-called kinetic isotope effect (KIE) and becomes apparent during the chemical reaction of a specific molecule $X$ :

$X_{\mathrm{L}}+E \stackrel{k_{\mathrm{L}}}{\rightarrow} \mathrm{P}$

$X_{\mathrm{H}}+E \stackrel{k_{\mathrm{H}}}{\rightarrow} \mathrm{P}^{\prime}$,

with $X_{\mathrm{L}}$ being its light (major) and $X_{\mathrm{H}}$ its heavy (minor) isotopologue. $E$ and $\mathrm{P} / \mathrm{P}^{\prime}$ denote the reaction partner(s) and product(s), respectively. The value of the KIE is thereby defined as the ratio of the rate coefficients $k_{\mathrm{L}}$ and $k_{\mathrm{H}}$ (Bigeleisen, 2005), and its inverse is called the fractionation 
factor $\alpha$ :

$\mathrm{KIE}:=\frac{k_{\mathrm{L}}}{k_{\mathrm{H}}}=\frac{1}{\alpha}$.

The KIEs of the sink reactions of $\mathrm{CH}_{4}$ have been determined by Saueressig et al. (1995, 1996, 2001), and Crowley et al. (1999), among others, in laboratory measurements (see Table 1). Since the KIEs of $\mathrm{CH}_{4}$ isotopologues are partly temperature dependent, the KIEs are described by two parameters, $A$ and $B$, and are calculated as

$\mathrm{KIE}=A \cdot \exp (B / T)$,

with $T$ being the temperature in $\mathrm{K}$.

The largest KIE and therefore strongest fractionation effect is found for the reaction with $\mathrm{Cl}$, which especially influences the isotopic composition of $\mathrm{CH}_{4}$ in the middle and upper stratosphere (Saueressig et al., 1996; Bergamaschi et al., 1996). Conversely, the reaction with $O\left({ }^{1} \mathrm{D}\right)$ shows the lowest KIE, which furthermore does not show any temperature dependence. The KIE of the reaction with $\mathrm{OH}$ is temperature dependent with respect to deuterated methane $\left(\mathrm{CH}_{3} \mathrm{D}\right)$ but not with respect to methane containing ${ }^{13} \mathrm{C}\left({ }^{13} \mathrm{CH}_{4}\right.$ ) (Saueressig et al., 2001). Nair et al. (2005) estimated the rate coefficients of the photodissociation of $\mathrm{CH}_{4}$ and its major isotopologues for the planet Mars, which results in a calculated $\mathrm{KIE}=1.005$ for $\mathrm{CH}_{3} \mathrm{D}$ and a negligible isotopic fractionation for the ${ }^{13} \mathrm{C}$ isotopologue (Nixon et al., 2012). There is, especially for deuterium, a non-negligible fractionation during the soil-loss for $\mathrm{CH}_{4}$ (Snover and Quay, 2000; Maxfield et al., 2008). An average value for the overall soil loss is estimated as $\mathrm{KIE}_{\mathrm{CH}_{3} \mathrm{D}}^{\text {soil }}=1.0825$ and $\mathrm{KIE}_{13}^{\text {soil }} \mathrm{CH}_{4}=1.0196$ (Snover and Quay, 2000; Holmgren, 2006; Maxfield et al., 2008).

\section{The Modular Earth Submodel System (MESSy)}

The framework of the Modular Earth Submodel System (MESSy, used in the second version MESSy2, Jöckel et al., 2010) is based on the idea of modularizing a climate model in such a way that single components can be switched on and off independently, depending on the desired set-up, meeting the demands of current Earth system modelling in terms of flexibility and computational performance. The modularization enables the user to pick suitable submodels or easily expand the model with new ones. Presented here are the submodel $\mathrm{CH} 4$ and the auxiliary submodel TRacer SYNChronization (TRSYNC), which are implemented based on this framework.

For the application examples of the new submodels, MESSy is used together with the fifth-generation European Centre Hamburg general circulation model (ECHAM5, Roeckner et al., 2006). The ECHAM/MESSy Atmospheric Chemistry (EMAC) model is a numerical chemistry and climate simulation system that includes sub-models describing tropospheric and middle atmosphere processes and their interaction with oceans, land, and human influences (Jöckel et al., 2010). EMAC (ECHAM5 version 5.3.02, MESSy version 2.54, Jöckel et al., 2010, 2016) is applied in the given examples in the T42L90MA-resolution, i.e. with a spherical truncation of T42, which corresponds to a quadratic Gaussian grid of approx. 2.8 by $2.8^{\circ}$ in latitude and longitude and includes 90 vertical hybrid pressure levels from the Earth surface up to $0.01 \mathrm{hPa}$. MESSy allows the configuration of EMAC in several operational modes. The two basic ones are the GCM set-up without chemistry and the CCM setup with fully interactive chemistry, using, among other components, the Module Efficiently Calculating the Chemistry of the Atmosphere (MECCA, Sander et al., 2005) and the SCAVenging (SCAV, Tost et al., 2006) submodel to represent the chemical kinetics of EMAC in the gas phase and aqueous phase, respectively. They define the underlying chemical reaction mechanisms in troposphere, stratosphere, and lower mesosphere. MECCA and SCAV provide comprehensive mechanisms, combining state-of-the-art reactions and rate coefficients. The kinetic chemistry tagging technique (MECCA_TAG, Gromov et al., 2010) enables the user to tag selected chemical elements, without modifying the underlying standard chemical mechanism of MECCA. It can be applied for simulating isotopologues of trace gases with respect to selected isotopes. In order to do so, rare and abundant isotopologues of the species of interest (e.g. those containing atomic hydrogen, $\mathrm{H}$ ) are created in an extended set of reactions in the same chemical mechanism.

MESSy and its application in EMAC has been used in multiple studies (see the special issue of Atmospheric Chemistry and Physics https://www.atmos-chem-phys.net/ special_issue22.html, last access: 18 January 2021) and includes several submodels from contributing institutions. Further information on EMAC, MESSy, and its submodels can be found in Jöckel et al. (2010, 2016), on the website https: //www.messy-interface.org/ (last access: 18 January 2021), or in the accompanying papers documenting the specific submodels.

\section{The submodel CH4}

The MESSy submodel CH4 aims to close the gap between the operational modes of EMAC as a GCM without chemistry and as a CCM with the comprehensive chemical mechanisms of MECCA and SCAV. The basic concept of the submodel is to limit the chemical mechanism to the loss processes of methane and use predefined fields of the reaction partners $\mathrm{OH}, \mathrm{O}\left({ }^{1} \mathrm{D}\right)$, and $\mathrm{Cl}$ to reduce the computational demands.

The sink Reactions (R1)-(R4) in the $\mathrm{CH} 4$ submodel are parameterized as follows:

$\frac{\mathrm{d}\left[\mathrm{CH}_{4}\right]}{\mathrm{d} t}=\left(-k_{\mathrm{CH}_{4}+\mathrm{OH}} \cdot c_{\mathrm{air}} \cdot[\mathrm{OH}]\right.$ 
Table 1. Temperature-dependent KIEs of the sink reactions of $\mathrm{CH}_{4}$ described as $\mathrm{KIE}=A \cdot \exp (B / T)$. The KIEs are valid in the given temperature range $(T$, in $\mathrm{K})$.

\begin{tabular}{lrrrl}
\hline Reaction & $A$ & $B$ & $T$ & Reference \\
\hline $\mathrm{KIE}_{13}^{\mathrm{OH}}$ & 1.0039 & 0.0 & $200-300$ & Saueressig et al. (2001) \\
$\mathrm{KIE}_{13}^{\mathrm{O}\left({ }^{1} \mathrm{D}\right)}$ & 1.013 & 0.0 & $223-295$ & Saueressig et al. (2001) \\
$\mathrm{KIE}_{13}^{\mathrm{Cl}} \mathrm{CH}_{4}$ & 1.043 & 6.455 & $223-297$ & Saueressig et al. (1995), Crowley et al. (1999) \\
\hline $\mathrm{KIE}_{\mathrm{CH}}^{\mathrm{OH}}$ & 1.097 & 49.0 & $249-422$ & Saueressig et al. (2001) \\
$\mathrm{KIE}_{\left.\mathrm{CH}_{3} \mathrm{D} \mathrm{D}\right)}^{\mathrm{O}(\mathrm{D})}$ & 1.060 & 0.0 & $224-295$ & Saueressig et al. (2001) \\
$\mathrm{KIE}_{\mathrm{CH}_{3} \mathrm{D}}^{\mathrm{Cl}}$ & 1.278 & 51.31 & $223-295$ & Saueressig et al. (1996) \\
\hline
\end{tabular}

$$
\begin{aligned}
& -k_{\mathrm{CH}_{4}+\mathrm{O}\left({ }^{1} \mathrm{D}\right)} \cdot c_{\mathrm{air}} \cdot\left[\mathrm{O}\left({ }^{1} \mathrm{D}\right)\right] \\
& \left.-k_{\mathrm{CH}_{4}+\mathrm{Cl}} \cdot c_{\mathrm{air}} \cdot[\mathrm{Cl}]-j_{\mathrm{CH}_{4}+h v}\right) \cdot\left[\mathrm{CH}_{4}\right],
\end{aligned}
$$

where $[X]$ denotes the mixing ratio of species $X$ in mol mol ${ }^{-1}, c_{\text {air }}$ is the concentration of air in $\mathrm{cm}^{-3}, k_{\mathrm{R}}$ is the reaction rate coefficient of reaction $R$ in $\mathrm{cm}^{3} \mathrm{~s}^{-1}$, and $j_{\mathrm{CH}_{4}+h v}$ is the photolysis rate of $\mathrm{CH}_{4}$ in s ${ }^{-1}$.

The prescribed fields are taken either from existing simulation results with detailed chemistry, or from other data sources (e.g. reanalyses or projections). If $\mathrm{CH} 4$ is included in an EMAC CCM simulation (which is possible in the MESSy framework), the CH4 submodel can also be coupled to the reactant fields, which are calculated online during the same simulation by the chemical mechanism (i.e. MECCA). Although this does not reduce computational requirements, such a simulation configuration can be used, for example, if output of one of the additional options of the CH4 submodel (age and emission classes or isotopologues) is desired. In that case a second $\mathrm{CH}_{4}$ tracer is treated and oxidized by the reactants provided by the kinetic solver of the comprehensive chemical mechanism. The same applies for the photolysis rate of $\mathrm{CH}_{4}$, which can be prescribed as gridded data provided offline or calculated online by the submodel JVAL (Sander et al., 2014). In either case, the CH4 submodel does not alter the reactant educts. Hence there is no feedback onto the $\mathrm{CH}_{4}$ sink by the submodel. In the case of coupling to MECCA via the educts, the coupling is one-way only.

Figure 1 visualizes the conceptual differences between the MESSy submodel CH4 (left) and a CCM simulation with MECCA (right). MECCA simulates the entire chemical mechanism and therefore also includes the feedback onto the reaction partners (depicted in yellow) of $\mathrm{CH}_{4}$. Additionally, there is also a secondary feedback by the products from the $\mathrm{CH}_{4}$ sink reactions (e.g. $\mathrm{H}_{2} \mathrm{O}$ and $\mathrm{HO}_{2}$, depicted in blue), as the subsequent chemical processes are influenced by the products from the $\mathrm{CH}_{4}$ oxidation. Conversely, the $\mathrm{CH} 4$ submodel uses the prescribed fields of the reactant species to calculate the $\mathrm{CH}_{4}$ loss. This loss is included in the master tracer of the $\mathrm{CH} 4$ submodel (the present $\mathrm{CH}_{4}$ is reduced) but does not feed back onto the sink fields or any other chemical species. The only exception is $\mathrm{H}_{2} \mathrm{O}$, in the case when the hydrological feedback of $\mathrm{CH}_{4}$ oxidation is switched on. GCMs include $\mathrm{CH}_{4}$ foremost for its radiative impact as a greenhouse gas but also for its influence on SWV (e.g. MongeSanz et al., 2013; ECMWF, 2007; Austin et al., 2007; Boville et al., 2001; Mote, 1995). The CH4 submodel is therefore equipped with an optional feedback onto $\mathrm{H}_{2} \mathrm{O}$ to account for part of the secondary climate feedback of $\mathrm{CH}_{4}$. It is thereby assumed that two molecules of $\mathrm{H}_{2} \mathrm{O}$ are produced per oxidized $\mathrm{CH}_{4}$ molecule (le Texier et al., 1988), which is, however, only a rough approximation, as analysed by Frank et al. (2018). The approximation of two molecules $\mathrm{H}_{2} \mathrm{O}$ per oxidized $\mathrm{CH}_{4}$ molecule overestimates the $\mathrm{H}_{2} \mathrm{O}$ production in the lower stratosphere and underestimates the production in the upper stratosphere. It also does not account for the chemical loss of $\mathrm{H}_{2} \mathrm{O}$ in the mesosphere.

Note that soil loss is not explicitly included in the $\mathrm{CH} 4$ submodel, since the concept of dry deposition is already part of the EMAC submodel DDEP (Kerkweg et al., 2006a). An example of how to use DDEP to simulate the soil loss of $\mathrm{CH}_{4}$ is included in the Supplement to this paper.

The submodel $\mathrm{CH} 4$, with its four sink reactions of $\mathrm{CH}_{4}$, is considerably computationally cheaper compared to a fully interactive chemistry simulation using MECCA, which represents (depending on the chosen set-up) several hundred reactions (e.g. more than 300 in the base simulations of the Earth System Chemistry integrated Modelling (ESCiMo) project Jöckel et al., 2016). For example, a reference setup with MECCA requires about 250 node- $\mathrm{h}^{1}$ per simulated year, while a set-up with the $\mathrm{CH} 4$ submodel without MECCA requires only 30 node-h per year. These numbers are calculated for simulations conducted on the high-performance computer (HPC) Mistral at the German Climate Computing Center (Deutsches Klimarechenzentrum, DKRZ).

The presented framework of the reduced $\mathrm{CH}_{4}$ chemistry is applicable since $\mathrm{CH}_{4}$ is only reduced and not produced in the free atmosphere. Therefore, the discretization of the four reactions where $\mathrm{CH}_{4}$ is involved is sufficient to represent

\footnotetext{
${ }^{1}$ node-h: required wall-clock hours times applied HPC nodes.
} 
the chemical loss of $\mathrm{CH}_{4}$. Nevertheless, in order to achieve meaningful simulation results with the $\mathrm{CH} 4$ submodel, some prerequisites have to be met. Since the educts $\left(\mathrm{OH}, \mathrm{O}\left({ }^{1} \mathrm{D}\right)\right.$, and $\mathrm{Cl}$ ) are prescribed, there is no feedback on them. Thus, very large variations in $\mathrm{CH}_{4}$ mixing ratio, which would in reality influence the $\mathrm{CH}_{4}$ sink (Winterstein et al., 2019), are not representable by the $\mathrm{CH} 4$ submodel.

Furthermore, the set-up with the $\mathrm{CH} 4$ submodel also lacks any feedback on $\mathrm{O}_{3}$. In the atmosphere, the $\mathrm{O}_{3}$ chemistry is influenced by changes in $\mathrm{OH}$ (reduced by $\mathrm{CH}_{4}$ ), $\mathrm{H}_{2} \mathrm{O}$ (produced by $\mathrm{CH}_{4}$ ) and temperature (influenced by the radiatively active $\mathrm{CH}_{4}$ ). The $\mathrm{CH} 4$ submodel alters $\mathrm{H}_{2} \mathrm{O}$ and with that influences the radiation budget and hence the temperature; however, there is no feedback on $\mathrm{O}_{3}$ when the set-up does not include any other chemical mechanism. In a set-up where the $\mathrm{CH} 4$ submodel is not used in parallel to MECCA, $\mathrm{O}_{3}$ time series or climatologies are usually prescribed for the radiation scheme.

The first simulations using the $\mathrm{CH} 4$ submodel are presented in studies by Eichinger et al. (2015a, b), it was included in the simulations of the ESCiMo project (Jöckel et al., 2016), and it has been used for the $\mathrm{CH}_{4}$ forecast system presented by Nickl et al. (2020).

\subsection{Option I: age and emission classes}

The $\mathrm{CH}_{4}$ submodel includes an option for simulating age and emission classes. These classes, which can be specified by the user via a namelist, enable a precise distinction between $\mathrm{CH}_{4}$ source sectors and/or regions (emission classes), as well as further insight into the $\mathrm{CH}_{4}$ distribution over time (age classes). The term "emission class" thereby denotes a $\mathrm{CH}_{4}$ like tracer defined by the $\mathrm{CH} 4$ submodel. The assignment of specific emission fluxes (sectors and regions) to the tracers of the emission classes is handled by the submodel OFFEMIS (Kerkweg et al., 2006b). In our present example application these classes are subject to emissions being a combination of an emission sector (like wetlands, biomass burning, anthropogenic sources, etc.) and a region (e.g. continents or countries). One tracer, for example, thus traces anthropogenic $\mathrm{CH}_{4}$ emitted from Africa, as shown in Sect. 5.1. These additional diagnostic tracers are transported identically to the master $\mathrm{CH}_{4}$ tracer of the $\mathrm{CH} 4$ submodel and also experience the same sink reactions.

The time period represented by one age class can be chosen by the user. How the age and emission classes evolve over time is depicted in Fig. 2. $\mathrm{CH}_{4}$ of each emission class is propagated through a specific number of age classes. The emitted $\mathrm{CH}_{4}$ of a specific emission class is added to the tracer that corresponds to the first age class. After the selected time span it moves to the next "older" age class until it reaches the oldest. The oldest age class represents the background, since $\mathrm{CH}_{4}$ does not proceed further.

Which age evolving method is applied is also selectable. The $\mathrm{CH} 4$ submodel offers three options: (1) $\mathrm{CH}_{4}$ is passed on in one step after a user-defined time span, (2) $\mathrm{CH}_{4}$ is continuously passed on with respect to an user-defined time span, and (3) $\mathrm{CH}_{4}$ is passed on monthly with fixed time lag.

We define the state vector for emission class $i$ and age classes 1 to $N$ as follows:

$\boldsymbol{f}_{i}=\left(\begin{array}{c}f_{i 1} \\ f_{i 2} \\ \vdots \\ f_{i N}\end{array}\right)$.

The first two options are implemented according to

$\Delta \boldsymbol{f}_{i}=\frac{\mathbf{M} \cdot \boldsymbol{f}_{i}}{\Delta t}$,

with $\Delta f_{i}$ being the tendency of $f_{i}, \Delta t$ being the time step length, and $\mathbf{M}$ being a matrix defining the ageing step according to the chosen option. For option (1) this matrix looks like

$\mathbf{M}=\left(\begin{array}{cccccc}-1 & 0 & & \cdots & & 0 \\ 1 & -1 & & & & \\ & 1 & -1 & & & \vdots \\ & & & \ddots & \ddots & \\ 0 & & \ldots & & 1 & 0\end{array}\right)$.

This moves the current values of one age class tracer after a user-defined time span to the next older one. This option is not consistent with a Leapfrog time stepping using an Asselin filter and might cause numerical oscillations and negative values. It was implemented solely for testing purposes during development, but it is not recommended for real applications. The ageing step matrix $\mathbf{M}$ for option (2) is $\mathbf{M}^{\prime}$ :

$\mathbf{M}^{\prime}=\alpha \cdot \mathbf{M}$,

with $\alpha=\frac{\Delta t}{\tilde{T}}$ and $\tilde{T}$ being the user-defined time span indicating the binning width of the age class. This option carries out a quasi-continuous update of the age classes, as it moves a fraction $(\alpha)$ of the current age class to the next at every time step.

The third option is implemented for usage by a fixed-lag Kalman filter for inverse optimization. With this option, one age class represents 1 month, and at the end of 1 month all $\mathrm{CH}_{4}$ of one age class moves to the next. This option is specifically implemented to be consistent with the Leapfrog time stepping (cf. option 1). A preliminary application of the concept of using the age and emission classes for an inverse optimization using the fixed-lag Kalman filter has been shown by Frank (2018).

In order to reduce numerical errors, the age and emission classes are continuously constrained (i.e. in each model time step) to sum up to the master tracer and are scaled appropriately if the sum deviates. This procedure is done to avoid the accumulation of such numerical errors, which mainly 

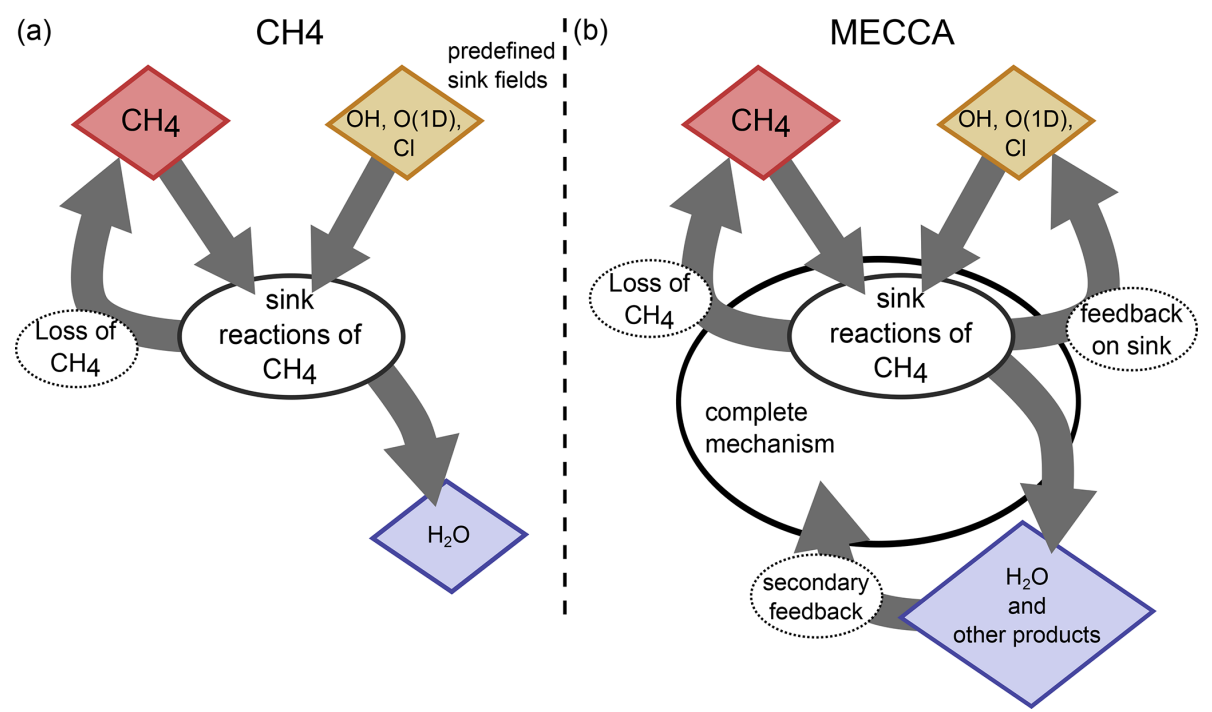

Figure 1. Sketch visualizing the concepts of parameterizing $\mathrm{CH}_{4}$ sink reactions in the MESSy submodels $\mathrm{CH} 4$ (a) and MECCA (b). The red species is the core species $\mathrm{CH}_{4}$. The chemical mechanism in $\mathrm{CH} 4$ is reduced to the sink reactions of $\mathrm{CH}_{4}$ and optionally includes the feedback to $\mathrm{H}_{2} \mathrm{O}$ (blue) only. In MECCA a complete chemical mechanism is included, which among others feeds back onto $\mathrm{H}_{2} \mathrm{O}$ and other products of the $\mathrm{CH}_{4}$ sink reactions, including the reaction partners (educts) of $\mathrm{CH}_{4}$. The reaction partners (yellow) in the $\mathrm{CH} 4$ submodel are prescribed and not changed by the $\mathrm{CH} 4$ submodel.

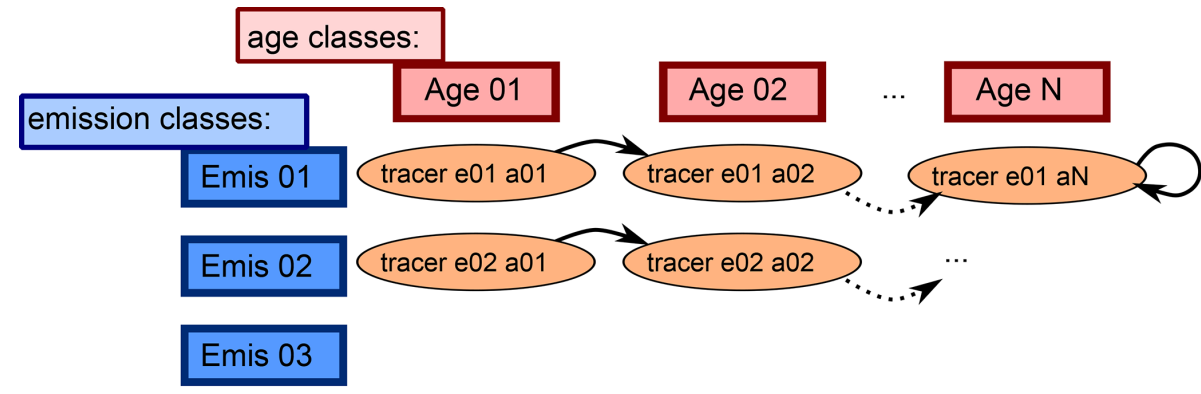

Figure 2. Sketch showing the advancing of the age classes in the $\mathrm{CH} 4$ submodel. Each tracer represents one specific emission and age class. After the defined length of time, the age classes proceed to the next "older" age class. The last class represents the background $\mathrm{CH}_{4}$, where the $\mathrm{CH}_{4}$ is only subject to transport and the chemically defined sink reactions but is not propagated to an older age class, which is indicated by the circled arrow.

arise from small non-linearities in the large-scale advection scheme. The magnitude therefore depends on the applied advection scheme but is usually on the order of the floating point precision.

\subsection{Option II: isotopologues}

In addition to solving the basic $\mathrm{CH}_{4}$ kinetics, the submodel $\mathrm{CH} 4$ also allows for the simulation of $\mathrm{CH}_{4}$ isotopologues, which are a potent diagnostic measure in the source and sink attribution. The submodel $\mathrm{CH} 4$ is able to simulate the abundant and first-order rare isotopologues and defines these as tracers additional to the master tracer. Higher substituted isotopologues are neglected. The user can choose whether isotopologues are simulated with respect to carbon ${ }^{12} \mathrm{CH}_{4}$ and $\left.{ }^{13} \mathrm{CH}_{4}\right)$, hydrogen $\left(\mathrm{CH}_{4}\right.$ containing ${ }^{1} \mathrm{H}$ isotopes only and $\mathrm{CH}_{3} \mathrm{D}$ ), or both. The abundant (with ${ }^{12} \mathrm{C}$ or ${ }^{1} \mathrm{H}$ isotopes only) and rare (with ${ }^{13} \mathrm{C}$ or $\mathrm{D}$ ) isotopologues are thereby simulated in parallel. During the simulation care is taken that each isotopologue family sums up to the master $\mathrm{CH}_{4}$ tracer of the $\mathrm{CH} 4$ submodel ( $\left.\mathrm{CH} 4 \_\mathrm{fx}\right)$. The isotopic signatures of $\mathrm{CH}_{4}$ emission sources are included by splitting the emission fluxes into an abundant and a rare fraction. This is handled via the OFFEMIS namelist (Kerkweg et al., 2006b; see the example namelists in the Supplement).

The rate coefficients of the $\mathrm{CH}_{4}$ isotopologues with their reaction partners are adjusted with respect to the KIE factors, e.g.

$\mathrm{KIE}=k_{\mathrm{CH}_{4}+\mathrm{OH}} / k_{\mathrm{CH}_{3} \mathrm{D}+\mathrm{OH}}$, 


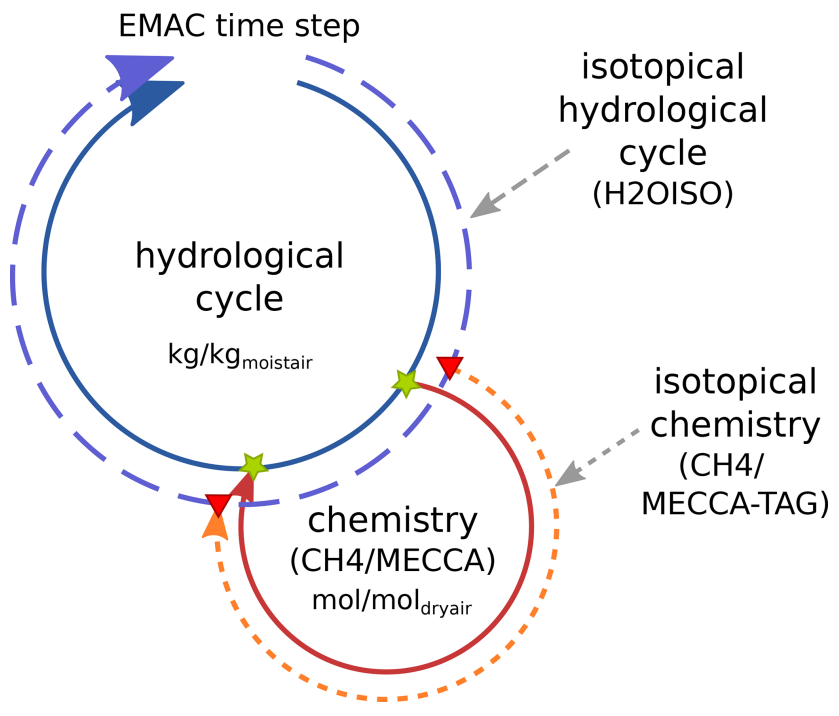

Figure 3. Sketch showing the coupling of the hydrological cycle and the chemistry (either $\mathrm{CH} 4$ or MECCA) with respect to $\mathrm{H}_{2} \mathrm{O}$ isotopologues in one time step of EMAC. Green stars indicate the points of the hydrological cycle, where (1) the current value of the water vapour master tracer is taken and (2) the chemical tendencies are added onto the water vapour master tracer. Red triangles indicate the synchronization points of the corresponding isotopical tracers by the TRSYNC submodel. Synchronization of the isotopological cycles also accounts for the appropriate unit conversion and adds the tendency of chemical processes to the fractionation in the physical hydrological cycle.

and are similar for reactions with $\mathrm{O}\left({ }^{1} \mathrm{D}\right), \mathrm{Cl}$, and photolysis. The applied reaction partners are thereby the same as those used for the master tracer.

To a certain extent the oxidation of $\mathrm{CH}_{3} \mathrm{D}$ produces deuterated water vapour (HDO). If the feedback of $\mathrm{CH}_{4}$ oxidation onto the hydrological cycle and the simulation of $\mathrm{D}$ containing isotopologues is switched on in the $\mathrm{CH} 4$ submodel, an additional tracer for HDO is created by the submodel and filled by the produced $\mathrm{HDO}$ from $\mathrm{CH}_{3} \mathrm{D}$ oxidation. There are two options available: (1) one oxidized $\mathrm{CH}_{3} \mathrm{D}$ produces one HDO molecule, or (2) the tendency of the HDO tracer is calculated by Eq. (9) (Eichinger et al., 2015a):

$$
\frac{\partial(\mathrm{HDO})}{\partial t}=\frac{-\frac{\partial\left(\mathrm{CH}_{3} \mathrm{D}\right)}{\partial t}+6.32 \times 10^{-5} \cdot \frac{\partial\left(\mathrm{CH}_{4}\right)}{\partial t}}{\frac{M_{\mathrm{air}}}{M_{\mathrm{HDO}}}\left(\frac{1}{1-\mathrm{HDO}}\right)^{2}},
$$

with $M_{\mathrm{air}}$ and $M_{\mathrm{HDO}}$ being the molar masses of air (28.987 $\mathrm{g} \mathrm{mol}^{-1}$ ) and HDO (19.02 $\left.\mathrm{g} \mathrm{mol}^{-1}\right)$, respectively. This empirical equation accounts for the $\mathrm{D}$, which stays in molecular hydrogen (HD) as it builds up to an equilibrium with $\mathrm{HDO}$ via the $\mathrm{HO}_{x}$ cycle.

\section{Coupling to the hydrological cycle with the new submodel TRSYNC}

In EMAC three different submodels are included that deal with isotopologues of $\mathrm{H}_{2} \mathrm{O}$ in the vapour phase: (1) the $\mathrm{CH} 4$ submodel presented here, (2) MECCA_TAG, and (3) $\mathrm{H}_{2} \mathrm{O}$ ISOtopologues (H2OISO, Eichinger et al., 2015a). CH4 and MECCA_TAG include the chemical fractionations, while $\mathrm{H} 2 \mathrm{OISO}$ is responsible for the physical fractionations in the hydrological cycle of the underlying GCM. All three create independent tracers of $\mathrm{H}_{2} \mathrm{O}$ isotopologues, which need to be synchronized to be able to combine physical and chemical fractionation effects of $\mathrm{H}_{2} \mathrm{O}$ and its isotopologues. The chemical fractionation is thereby considered either from MECCA_TAG or from $\mathrm{CH} 4$, although both submodels can be concurrently included in a simulation and compute the isotopic fractionation independently.

In principle, if EMAC is applied in GCM mode, only the master hydrological cycle is present (see Fig. 3, inner blue circle). Adding MECCA or $\mathrm{CH} 4$ to the set-up expands the model into a CCM or a simple " $\mathrm{CH}_{4}$-only" $\mathrm{CCM}$, respectively (solid red circle). The chemistry submodels use water vapour as a chemical tracer (first green star) and calculate the contribution from $\mathrm{CH}_{4}$ oxidation (second green star). This chemical feedback onto water vapour was already implemented as an option in previous EMAC versions. By including the isotopological submodels into the set-up, $\mathrm{H} 2 \mathrm{OISO}$ duplicates the hydrological cycle for the water isotopologues and CH4 or MECCA_TAG creates the chemical tracers of the water isotopologues (outer dashed circles). This results in several physical and chemical $\mathrm{H}_{2} \mathrm{O}$ isotopologue tracers. While the master chemical process adds its feedback directly to the specific humidity of the hydrological cycle (there is no need for a chemical water tracer), the synchronization of the physical isotopological tracers in the isotopic hydrological cycle (H2OISO) and the chemical isotopological tracers (CH4 or MECCA_TAG) is done via the new auxiliary submodel TRSYNC. In brief, TRSYNC guarantees that the physical $\mathrm{H}_{2} \mathrm{O}$ tracers (including their isotopologues) also receive the correct tendencies of the corresponding chemical tracers. Since isotopological water vapour tracers of MECCA_TAG and the HDO tracer created by $\mathrm{CH} 4$ are transported in EMAC in the same way as every other tracer, they are subject to some of the physical processes but not to all hydrological fractionation effects. Thus, at the first synchronization point the chemical tracer is synchronized to represent the current value of the physical tracer. In the following, chemical tendencies including fractionation effects are calculated and are added via the second synchronization point to the physical tracer. By doing so, chemical and physical fractionation processes are strictly separated and the tendencies of the chemical tracers represent the chemical tendencies in addition to the previous physical fractionations in the current time step. 
Water vapour in the physical hydrological cycle (regarding ECHAM5 and H2OISO) is defined in units of kilograms of the tracer per kilogram of moist air $\left(\mathrm{kg} \mathrm{kg}^{-1}\right.$ moist air $)$, while the chemical tracers are defined in units of $\mathrm{mol} \mathrm{mol}^{-1}$ dry air. This also holds for the corresponding isotopologue tracers. Parameterizations of physical processes in ECHAM5 are by design formulated with specific humidity (per moist air). Conversely, chemical reactions are necessarily calculated with species concentrations. This requires the individual chemical and physical isotopologue tracers, which have, for the sake of correct process formulations, distinct units, and motivated the development of the auxiliary submodel TRSYNC in order to be able to synchronize these tracers accordingly in the same way for CH4 and MECCA_TAG.

In addition to that, the application of MECCA_TAG creates the basis to investigate various other isotopes in the interactive chemical mechanism. While $\mathrm{CH} 4$ feedbacks onto $\mathrm{H}_{2} \mathrm{O}$ with respect to hydrogen isotopes only, MECCA_TAG can also be used to simulate oxygen isotopes $\left({ }^{16} \mathrm{O},{ }^{17} \mathrm{O}\right.$ and $\left.{ }^{18} \mathrm{O}\right)$ in the chemical mechanism. It is therefore also possible to couple MECCA_TAG with oxygen isotopes to the corresponding oxygen-related isotopologue tracers in H2OISO. Last but not least, for MECCA_TAG tracer names are not standardized. Therefore, the namelist of the submodel TRSYNC can be adjusted according to the actual tracer names used in MECCA_TAG.

\section{Example applications}

The following examples are simulations carried out with EMAC in a GCM-like mode, including the newly presented CH4 and TRSYNC submodels. Other involved MESSy submodels are OFFEMIS (Kerkweg et al., 2006b) and DDEP (Kerkweg et al., 2006a). OFFEMIS manages the emissions of $\mathrm{CH}_{4}$ from prescribed sources. It reads predefined fields with emission data and adds these fluxes to the chemical tracers. DDEP simulates the dry deposition for gases and aerosols and is used in the present context to simulate the soil loss of $\mathrm{CH}_{4}$, which is not done in the $\mathrm{CH} 4$ submodel itself.

Monthly mean sink fields are used in the simulation setup in the examples below. Higher frequencies are technically possible; this would, however, increase the computational demands due to the larger amount of data read from disk. Monthly mean fields smooth the diurnal cycle, which is especially strong in $\mathrm{OH}$. However, in order to investigate long-term global trends of $\mathrm{CH}_{4}$, which has a tropospheric lifetime of 8-10 years, variations on timescales of less than 1 month are negligible, and monthly mean fields are assumed to suffice for such applications. Furthermore, in these examples photolysis rates are calculated by the submodel JVAL in the presented examples, but predefined data can be used as well.

The H2OISO submodel (Eichinger, 2014; Eichinger et al., 2015a) simulates the stable water isotopologues with re- spect to $\mathrm{H}$ and $\mathrm{D}$, as well as ${ }^{16} \mathrm{O},{ }^{17} \mathrm{O}$, and ${ }^{18} \mathrm{O}$. Overall, it represents a second hydrological cycle, which includes water isotopologues in their three phases: gas, liquid, and ice. $\mathrm{H} 2 \mathrm{OISO}$ accounts for fractionation processes during phase transitions in large-scale and convective clouds, during vertical diffusion, and during evaporation from the ocean (evaporation from soil, the biosphere, and snow are not considered to have a significant fractionation).

We simulated the years 1989 to 2012 and applied a specified dynamics set-up to represent the reanalysed meteorology of this time. Specified dynamics means here that the prognostic variables divergence, vorticity, temperature, and (logarithm of) surface pressure are nudged by Newtonian relaxation towards ECMWF ERA-Interim reanalysis data (Dee et al., 2011).

\subsection{Application of the $\mathrm{CH} 4$ submodel for inverse optimization of $\mathrm{CH}_{4}$ emission inventories}

Current estimates of $\mathrm{CH}_{4}$ emission inventories still include large uncertainties. In order to reduce these, new estimates of inventories must be able to represent temporal and spatial resolutions in greater detail (e.g. seasonal cycle, distinct regions). One statistical method to estimate $\mathrm{CH}_{4}$ emission strengths is the fixed-lag Kalman filter, which performs an inverse optimization of the emission inventory by comparing simulated and observed mixing ratios of a trace gas (see, e.g. Bruhwiler et al., 2005). This "offline" inversion algorithm requires data from a forward simulation, including temporal and spatial information of the simulated $\mathrm{CH}_{4}$ tracer.

In order to provide the necessary data, the $\mathrm{CH} 4$ submodel with the option of age and emission classes is applied. The combination of chosen regions and emission sectors in this example results in 48 emission classes altogether. These 48 emission classes are simulated with 5 age classes for ages up to $1,2,3,4$, and $\geq 5$ months since emission release. Figure 4 exemplarily shows the evolution of a single emission class (i.e. anthropogenic emissions in Africa) from age class to age class. Figure $4 \mathrm{a}$ shows the emissions of the year 2000 in $\mathrm{g}\left(\mathrm{CH}_{4}\right) \mathrm{m}^{-2} \mathrm{yr}^{-1}$. Figure $4 \mathrm{~b}-\mathrm{f}$ show the age classes in ascending order and display the distribution of the $\mathrm{CH}_{4}$ mixing ratio onto the five age classes in January 2000 (the simulation has started in 1989). In the fourth age class the $\mathrm{CH}_{4}$ from anthropogenic African sources is almost evenly distributed, mostly in the Northern Hemisphere (NH). Eventually, the fifth age class (i.e. the last age class) shows the accumulated background of all $\mathrm{CH}_{4}$ from anthropogenic African sources. An a priori emission inventory is applied in the example situation.

Overall, the temporal evolution of the age classes in Fig. 4 confirms that the five age classes in this set-up sufficiently track the spread of $\mathrm{CH}_{4}$ towards a fairly uniform distribution, which is a prerequisite for a successful application of the inverse optimization method. 


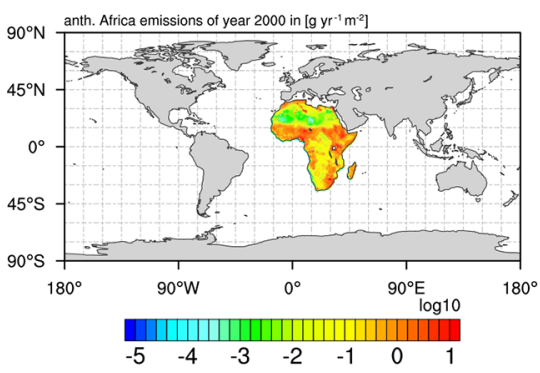

(a)

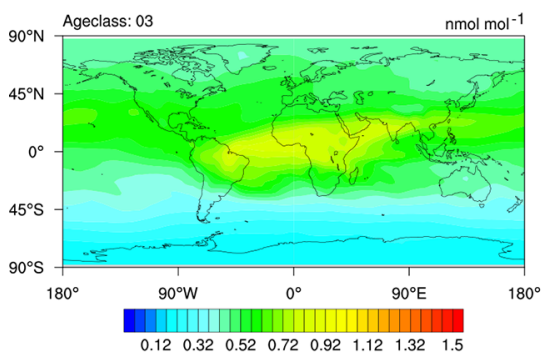

(d)

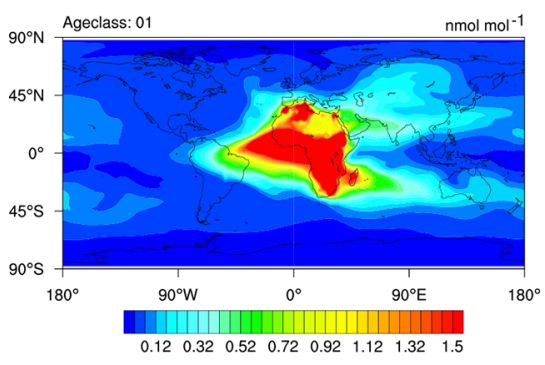

(b)

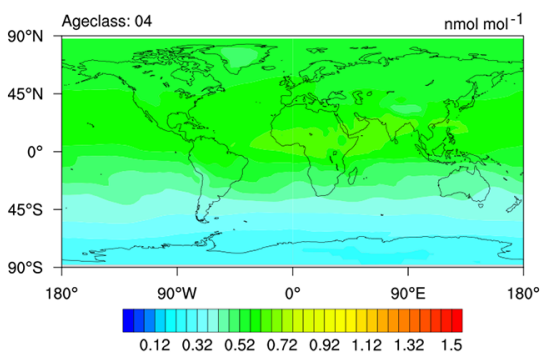

(e)

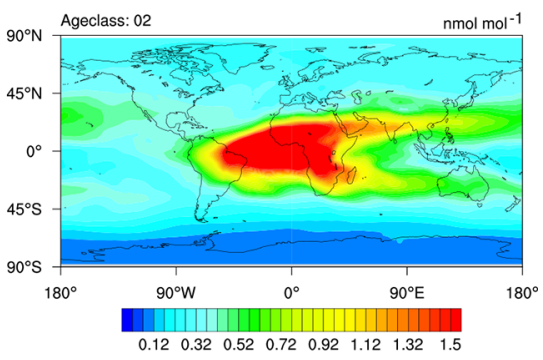

(c)

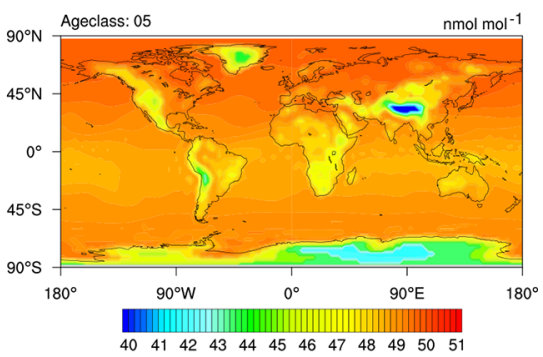

(f)

Figure 4. (a) Anthropogenic emissions in Africa (taken from EDGARv4.2 2010 fast-track database; Olivier and Janssens-Maenhout, 2012). (b-f) Methane as a pressure-weighted column up to $200 \mathrm{hPa}$ of anthropogenic origin from Africa, distributed into five age classes, i.e. up to $1,2,3$, and 4 , and $\geq 5$ months after emission release. As an example, all age classes of January 2000 after the simulation has run for 12 years are shown.

\subsection{Simulating $\mathrm{CH}_{4}$ isotopologues}

We further present a simulation using the $\mathrm{CH} 4$ submodel, which includes all four $\mathrm{CH}_{4}$ isotopologues. For this simulation, we applied a global a posteriori emission inventory provided by Dominik Brunner (personal communication, 2017) and a set of isotopic emission signatures prepared from data from the literature (see Table S1 in the Supplement).

Figure 5 shows zonal mean climatologies (2000-2009) of $\mathrm{CH}_{4}$ in $\mathrm{nmol} \mathrm{mol}^{-1}$ and the corresponding isotopic signature in \%o. The isotopologues are displayed in the $\delta$ notation with respect to the reference isotope ratios Vienna PeeDee Belemnite (VPDB) for ${ }^{13} \mathrm{CH}_{4}$, and Vienna Standard Mean Ocean Water (VSMOW) for $\mathrm{CH}_{3} \mathrm{D}$, respectively. In the troposphere the NH is isotopically depleted compared to the Southern Hemisphere (SH). Most isotopically light emissions, for example from wetlands and rice, are located in the $\mathrm{NH}$, while isotopically heavy sources like biomass burning are mostly located in the SH. This results in the prevalent tropospheric north-south gradient. In the stratosphere $\mathrm{CH}_{4}$ becomes isotopically enriched towards higher altitudes. When $\mathrm{CH}_{4}$ is ascending in the atmosphere it is exposed to oxidation. Due to fractionation processes, heavy $\mathrm{CH}_{4}$ isotopologues are unfavoured and therefore accumulate in the remaining $\mathrm{CH}_{4}$.

Our simulation results compare well to observations. For example, isotopic observations from the National Oceanic and Atmospheric Administration/Earth System Research
Laboratory (NOAA/ESRL) sampling sites (White et al., 2016, 2017) and airborne samples taken during the Comprehensive Observation Network for TRace gases by AIrLiner (CONTRAIL) project (Umezawa et al., 2012) verify the north-south gradient (shown Sect. S2.1 and S2.2 in the Supplement). The values of the signature of ${ }^{13} \mathrm{C}$ in $\mathrm{CH}_{4}\left({ }^{13} \mathrm{C}\left(\mathrm{CH}_{4}\right)\right)$, for example, are within the uncertainty of the CONTRAIL observations. The signature of $\mathrm{D}$ in $\mathrm{CH}_{4}$ $\left(\delta \mathrm{D}\left(\mathrm{CH}_{4}\right)\right)$ is isotopologically depleted in $\mathrm{D}$ compared to the CONTRAIL observations; however, it still captures the gradient well. The vertical gradient (i.e. isotopical enrichment in the stratosphere) can be verified by comparing it with balloon-borne observations by Röckmann et al. (2011). Our simulation results are thereby within the local and temporal uncertainties (shown in Sect. S2.3 in the Supplement). Note that an optimization with respect to source signatures is yet to be made and requires an optimized emission inventory. However, the capturing of the respective gradients indicates that the isotopical fractionation is sufficiently implemented.

\subsection{Coupling of the $\mathrm{CH}_{4}$ isotopologues to the isotopological hydrological cycle}

The previously shown results were achieved with the $\mathrm{CH} 4$ submodel, including the option to simulate $\mathrm{CH}_{4}$ isotopologues. The produced HDO (by oxidation of $\mathrm{CH}_{3} \mathrm{D}$ ) is connected via the TRSYNC submodel to the isotopological hy- 


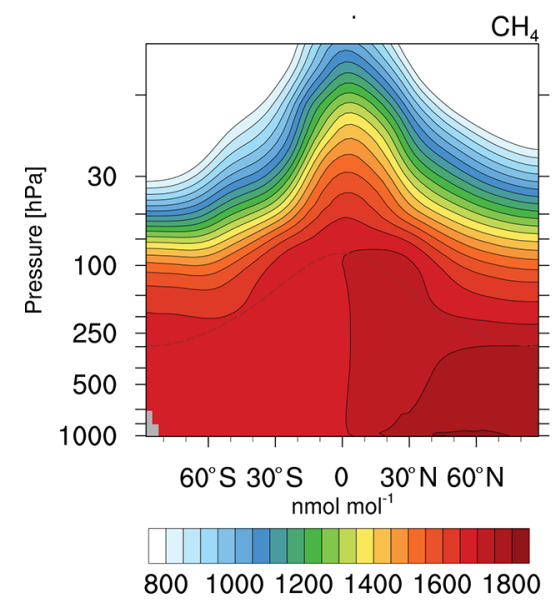

(a)

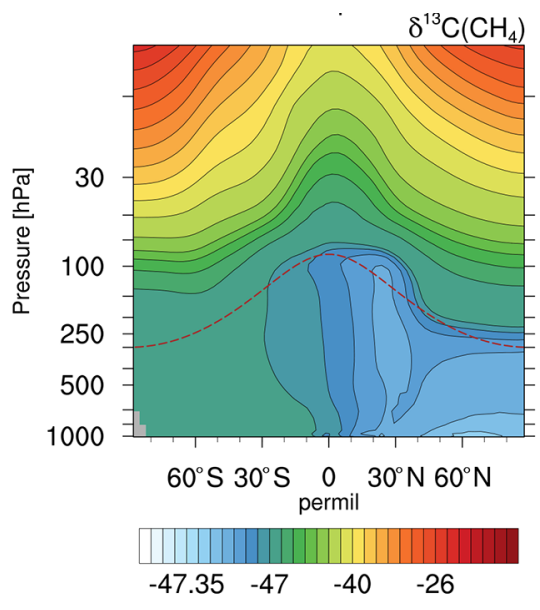

(b)

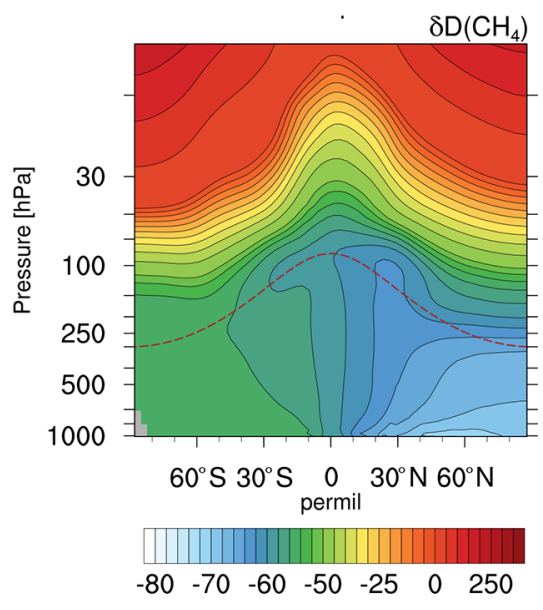

(c)

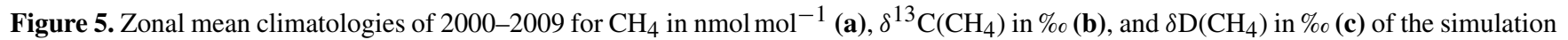
with EMAC and the $\mathrm{CH} 4$ submodel. The dashed brown lines indicate the height of the climatological tropopause.

Sim. with $\mathrm{CH} 4$

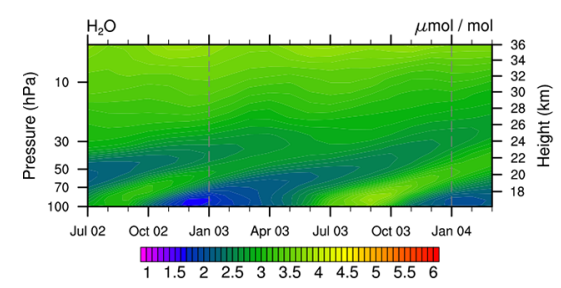

(a)

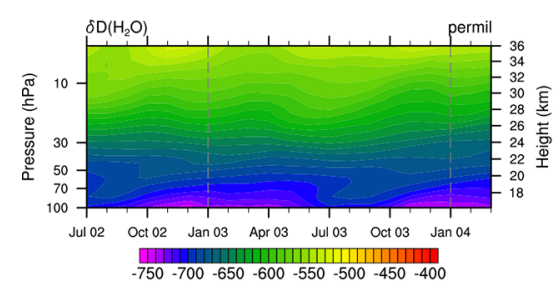

(d)

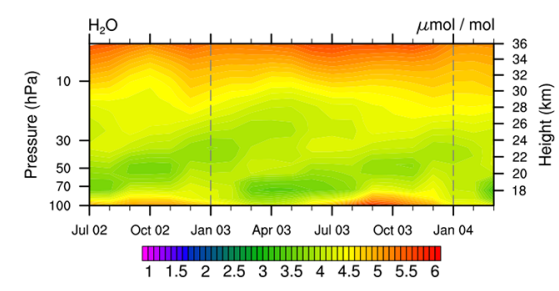

(b)

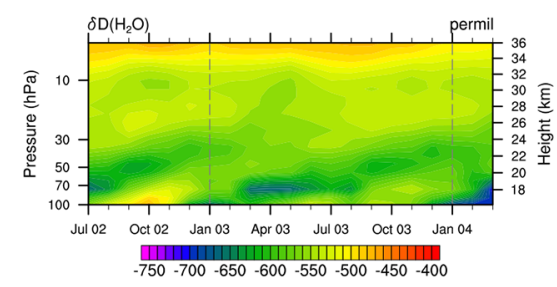

(e)
Sim. with MECCA-TAG

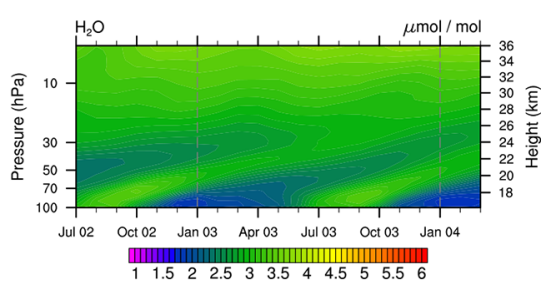

(c)

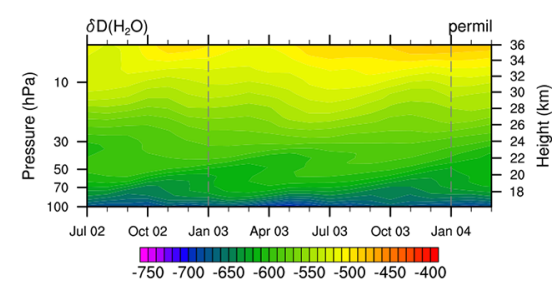

(f)

Figure 6. Tropical stratospheric tape recorder signal of $\mathrm{H}_{2} \mathrm{O}(\mathbf{a}, \mathbf{b}, \mathbf{c})$ and $\delta \mathrm{D}\left(\mathrm{H}_{2} \mathrm{O}\right)(\mathbf{d}, \mathbf{e}, \mathbf{f})$ in MIPAS data (b, e) and the simulations with the CH4 submodel (a, d) and the MECCA_TAG submodel (c, f) in the time period July 2002 to March 2004. Simulation data are averaged monthly, zonally, and over the tropics between $23^{\circ} \mathrm{S}-23^{\circ} \mathrm{N}$ and are displayed between 100 and $1 \mathrm{hPa}$. The dashed grey lines are included for eye guidance in the comparison of the tape recorder signal.

drological cycle represented by the H2OISO submodel. We carried out an additional simulation in which we applied MECCA and MECCA_TAG to simulate the atmospheric chemistry and the $\mathrm{CH}_{4}$ isotopologues instead of the $\mathrm{CH} 4$ submodel. In this simulation TRSYNC likewise connects the produced HDO to the isotopological water tracers of H2OISO.
In Fig. 6 we compare the results obtained with submodel $\mathrm{CH} 4$ (left) and those obtained with the submodel MECCA_TAG (right) to vertical profiles of $\mathrm{H}_{2} \mathrm{O}$ and HDO (middle) provided by the Michelson Interferometer for Passive Atmospheric Sounding (MIPAS) instrument mounted on the ENVIronmental SATellite (ENVISAT, Steinwagner et al., 2007; Lossow et al., 2011). The ENVISAT satellite is on a sun-synchronous orbit around the Earth, completing the cir- 
cuit 14 times a day. The presented observational and simulated data comprise the time period July 2002 to March 2004. The vertical range of the observations extends from 6 to $68 \mathrm{~km}$ (i.e. approx. the range $100-1 \mathrm{hPa}$ ) with a vertical resolution of $3-8 \mathrm{~km}$. Simulation and observation data are monthly and zonally averaged over the tropics. Similar to the conclusions of Eichinger et al. (2015a) it is observed that the EMAC model underestimates the $\mathrm{H}_{2} \mathrm{O}$ mixing ratio (see Figs. 6a and c). This is associated with a too cold tropopause in EMAC, where a temperature bias of -2 to $-6 \mathrm{~K}$ is detected in the upper troposphere, as long as the mean temperature is excluded from the nudging procedure defining the specified dynamics set-up (Jöckel et al., 2016). This reduces the $\mathrm{H}_{2} \mathrm{O}$ transported into the stratosphere since more gas-phase $\mathrm{H}_{2} \mathrm{O}$ freezes and sediments. Comparing Fig. 6d with $\mathrm{f}$ indicates a better agreement concerning the signature of $\mathrm{D}$ in $\mathrm{H}_{2} \mathrm{O}\left(\delta \mathrm{D}\left(\mathrm{H}_{2} \mathrm{O}\right)\right)$ in the simulation using the submodel MECCA_TAG with the MIPAS observations, which suggests that although the absolute $\mathrm{H}_{2} \mathrm{O}$ and $\mathrm{HDO}$ mixing ratios are not met, the relative composition is well represented. The differences in HDO in the simulation with the $\mathrm{CH} 4$ submodel compared to the one with the MECCA_TAG submodel and MIPAS are potentially caused by (1) the Eq. (9) from Eichinger et al. (2015a) used in the simulation using the $\mathrm{CH} 4$ submodel, which possibly does not capture important fractionation processes in the oxidation chain of $\mathrm{CH}_{3} \mathrm{D}$, and (2) the HD produced in the troposphere and propagating into the stratosphere, which is not included in the simplified chemistry but represents an additional source of HDO. For an accurate simulation of stratospheric HDO this source also needs to be considered in future simulations.

\section{Summary}

The submodel $\mathrm{CH} 4$ provides a reduced chemical set-up focusing on the $\mathrm{CH}_{4}$ sink reactions using predefined data of reaction partners and optionally includes the feedback on SWV. This reduces the computational demands of sensitivity simulations of climate projections without neglecting the main source of chemically induced SWV.

We present two additional options of the $\mathrm{CH} 4$ submodel. The age and emission classes allow the inverse optimization of emission inventories using a fixed-lag Kalman filter. The simulation of $\mathrm{CH}_{4}$ isotopologues provides further insight into the variability and distribution of $\mathrm{CH}_{4}$ from its source (via emission signatures and fractionation effects) to its sink (coupling to the isotopic content of $\mathrm{H}_{2} \mathrm{O}$ ). The latter is implemented in form of the new submodel TRSYNC, which takes care of the correct and time-integration-conform synchronization of the various $\mathrm{H}_{2} \mathrm{O}$ isotopologue tracers in the model.

Example use cases show specific applications of the $\mathrm{CH} 4$ submodel and the coupling to the isotopological hydrological cycle via the TRSYNC submodel, which is especially helpful for the closure of the isotopic content in SWV.

Code and data availability. The Modular Earth Submodel System (MESSy) is continuously further developed and applied by a consortium of institutions. The usage of MESSy and access to the source code is licensed to all affiliates of institutions that are members of the MESSy Consortium. Institutions can become a member of the MESSy Consortium by signing the MESSy Memorandum of Understanding. More information can be found on the MESSy Consortium website (http://www.messy-interface.org, last access: 18 January 2021). The new submodels presented in this paper have been implemented based on MESSy v2.53.0 and have been available since v2.54.0. The exact code version used to produce the examples is archived at the German Climate Computing Center (Deutsches Klimarechenzentrum, DKRZ) and can be made available to members of the MESSy community upon request.

Supplement. The supplement related to this article is available online at: https://doi.org/10.5194/gmd-14-661-2021-supplement.

Author contributions. FW and PJ worked on the development of the $\mathrm{CH} 4$ and TRSYNC submodels and wrote the manuscript.

Competing interests. The authors declare that they have no conflict of interest.

Acknowledgements. The model simulations have been performed at the German Climate Computing Centre (DKRZ) through support from the Bundesministerium für Bildung und Forschung (BMBF). We further thank Theresa Klausner and two anonymous reviewers for their supportive comments on the manuscript.

Financial support. The DLR project KliSAW (Klimarelevanz von atmosphärischen Spurengasen, Aerosolen und Wolken) and the Helmholtz-Gemeinschaft e.V. (HGF) "Project Advanced Earth System Modelling Capacity (ESM)" provided the financial basis for the presented model developments.

The article processing charges for this open-access publication were covered by a Research Centre of the Helmholtz Association.

Review statement. This paper was edited by Fiona O'Connor and reviewed by two anonymous referees. 


\section{References}

Austin, J., Wilson, J., Li, F., and Vömel, H.: Evolution of Water Vapor Concentrations and Stratospheric Age of Air in Coupled Chemistry-Climate Model Simulations, B. Am. Meteorol. Soc., 64, 905-921, https://doi.org/10.1175/JAS3866.1, 2007.

Bergamaschi, P., Brühl, C., Brenninkmeijer, C. A. M., Saueressig, G., Crowley, J. N., Grooß, J. U., Fischer, H., and Crutzen, P. J.: Implications of the large carbon kinetic isotope effect in the reaction $\mathrm{CH}_{4}+\mathrm{Cl}$ for the ${ }^{13} \mathrm{C} /{ }^{12} \mathrm{C}$ ratio of stratospheric $\mathrm{CH}_{4}$, Geophys. Res. Lett., 23, 2227-2230, https://doi.org/10.1029/96GL02139, 1996.

Bigeleisen, J.: Isotope Effects in Chemistry and Biology, chap. 01, Theoretical Basis of Isotope Effects from an Autobiographical Perspective, Taylor and Taylor and Francis Group, LLC, 1-40, https://doi.org/10.1201/9781420028027, 2005.

Boville, B. A., Kiehl, J. T., Rasch, P. J., and Bryan, F. O.: Improvements to the NCAR CSM-1 for Transient Climate Simulations, J. Climate, 14, 164-179, https://doi.org/10.1175/15200442(2001)014<0164:ITTNCF>2.0.CO;2, 2001.

Bruhwiler, L. M. P., Michalak, A. M., Peters, W., Baker, D. F., and Tans, P.: An improved Kalman Smoother for atmospheric inversions, Atmos. Chem. Phys., 5, 2691-2702, https://doi.org/10.5194/acp-5-2691-2005, 2005.

Crowley, J. N., Saueressig, G., Bergamaschi, P., Fischer, H., and Harris, G. W.: Carbon kinetic isotope effect in the reaction $\mathrm{CH}_{4}+\mathrm{Cl}$ : a relative rate study using FTIR spectroscopy, Chem. Phys. Lett., 303, 268-274, https://doi.org/10.1016/S00092614(99)00243-2, 1999.

Dee, D. P., Uppala, S. M., Simmons, A. J., Berrisford, P., Poli, P., Kobayashi, S., Andrae, U., Balmaseda, M. A., Balsamo, G., Bauer, P., Bechtold, P., Beljaars, A. C. M., van de Berg, L., Bidlot, J., Bormann, N., Delsol, C., Dragani, R., Fuentes, M., Geer, A. J., Haimberger, L., Healy, S. B., Hersbach, H., Hólm, E. V., Isaksen, L., Kållberg, P., Köhler, M., Matricardi, M., McNally, A. P., Monge-Sanz, B. M., Morcrette, J.J., Park, B.-K., Peubey, C., de Rosnay, P., Tavolato, C., Thépaut, J.-N., and Vitart, F.: The ERA-Interim reanalysis: configuration and performance of the data assimilation system, Q. J. Roy. Meteor. Soc., 137, 553-597, https://doi.org/10.1002/qj.828, https://doi.org/10.1002/qj.828, 2011.

ECMWF: IFS DOCUMENTATION - Cy31r1, Part IV: Physical Processes, available at: https://www.ecmwf.int/sites/default/files/ elibrary/2007/9221-part-iv-physical-processes.pdf (last access: 18 January 2021), 2007.

Eichinger, R.: Investigation of stratospheric water vapour by means of the simulation of water isotopologues, $\mathrm{PhD}$ thesis, Ludwig Maximilian Universität München, München, 2014.

Eichinger, R., Jöckel, P., Brinkop, S., Werner, M., and Lossow, S.: Simulation of the isotopic composition of stratospheric water vapour Part 1: Description and evaluation of the EMAC model, Atmos. Chem. Phys., 15, 5537-5555, https://doi.org/10.5194/acp-15-5537-2015, 2015a.

Eichinger, R., Jöckel, P., and Lossow, S.: Simulation of the isotopic composition of stratospheric water vapour Part 2: Investigation of $\mathrm{HDO} / \mathrm{H}_{2} \mathrm{O}$ variations, Atmos. Chem. Phys., 15, 7003-7015, https://doi.org/10.5194/acp-15-7003-2015, 2015b. 2015b.

Fletcher, M., E., S., Tans, P. P., Bruhwiler, L. M., Miller, J. B., and Heimann, $\mathrm{M}$.: $\mathrm{CH}_{4}$ sources estimated from atmospheric observations of $\mathrm{CH}_{4}$ and its ${ }^{13} \mathrm{C} /{ }^{12} \mathrm{C}$ isotopic ratios: 2. Inverse modeling of $\mathrm{CH}_{4}$ fluxes from geographical regions, Global Biogeochem. Cy., 18, 1-15, https://doi.org/10.1029/2004GB002224, 2004.

Frank, F.: Atmospheric methane and its isotopic composition in a changing climate: A modelling study, PhD thesis, Ludwigs Maximillian Universität München, München, 2018.

Frank, F., Jöckel, P., Gromov, S., and Dameris, M.: Investigating the yield of $\mathrm{H}_{2} \mathrm{O}$ and $\mathrm{H}_{2}$ from methane oxidation in the stratosphere, Atmos. Chem. Phys., 18, 9955-9973, https://doi.org/10.5194/acp-18-9955-2018, 2018.

Gromov, S., Jöckel, P., Sander, R., and Brenninkmeijer, C. A. M.: A kinetic chemistry tagging technique and its application to modelling the stable isotopic composition of atmospheric trace gases, Geosci. Model Dev., 3, 337-364, https://doi.org/10.5194/gmd-3337-2010, 2010.

Hein, R., Crutzen, P. J., and Heimann, M.: An inverse modeling approach to investigate the global atmospheric methane cycle, Global Biogeochem. Cy., 11, 43-76, 1997.

Holmgren, P.: Global land use area change matrix, Working Paper 134, Forest Resources Assessment Programme, Food and Agriculture Organization of the United Nations, Rome, Italy, 2006.

IPCC: Climate Change 2013: The Physical Science Basis. Contribution of Working Group I to the Fifth Assessment Report of the Intergovernmental Panel on Climate Change, Cambridge University Press, Cambridge, UK and New York, NY, USA, https://doi.org/10.1017/CBO9781107415324, 2013.

Jöckel, P., Kerkweg, A., Pozzer, A., Sander, R., Tost, H., Riede, H., Baumgaertner, A., Gromov, S., and Kern, B.: Development cycle 2 of the Modular Earth Submodel System (MESSy2), Geosci. Model Dev., 3, 717-752, https://doi.org/10.5194/gmd-3717-2010, 2010.

Jöckel, P., Tost, H., Pozzer, A., Kunze, M., Kirner, O., Brenninkmeijer, C. A. M., Brinkop, S., Cai, D. S., Dyroff, C., Eckstein, J., Frank, F., Garny, H., Gottschaldt, K.-D., Graf, P., Grewe, V., Kerkweg, A., Kern, B., Matthes, S., Mertens, M., Meul, S., Neumaier, M., Nützel, M., Oberländer-Hayn, S., Ruhnke, R., Runde, T., Sander, R., Scharffe, D., and Zahn, A.: Earth System Chemistry integrated Modelling (ESCiMo) with the Modular Earth Submodel System (MESSy) version 2.51, Geosci. Model Dev., 9, 1153-1200, https://doi.org/10.5194/gmd-9-1153-2016, 2016.

Kerkweg, A., Buchholz, J., Ganzeveld, L., Pozzer, A., Tost, H., and Jöckel, P.: Technical Note: An implementation of the dry removal processes DRY DEPosition and SEDImentation in the Modular Earth Submodel System (MESSy), Atmos. Chem. Phys., 6, 4617-4632, https://doi.org/10.5194/acp-6-4617-2006, 2006a.

Kerkweg, A., Sander, R., Tost, H., and Jöckel, P.: Technical note: Implementation of prescribed (OFFLEM), calculated (ONLEM), and pseudo-emissions (TNUDGE) of chemical species in the Modular Earth Submodel System (MESSy), Atmos. Chem. Phys., 6, 3603-3609, https://doi.org/10.5194/acp-6-3603-2006, 2006 b.

King, G.: Responses of atmospheric methane consumption by soils to global climate change, Glob. Change Biol., 3, 351-362, https://doi.org/10.1046/j.1365-2486.1997.00090.x, 1997.

Kirschke, S., Bousquet, P., Ciais, P., Saunois, M., Canadell, J. G., Dlugokencky, E. J., Bergamaschi, P., Bergmann, D., Blake, D. R., Bruhwiler, L., Cameron-Smith, P., Castaldi, S., Chevallier, F., Feng, L., Fraser, A., Heimann, M., Hodson, E. L., Houweling, S., Josse, B., Fraser, P. J., Krummel, P. B., Lamarque, J.-F., Langenfelds, R. L., Le Quèrè, C., Naik, V., O’Doherty, S., Palmer, P. I., 
Pison, I., Plummer, D., Poulter, B., Prinn, R. G., Rigby, M., Ringeval, B., Santini, M., Schmidt, M., Shindell, D. T., Simpson, I. J., Spahni, R., Steele, L. P., Strode, S. A., Sudo, K., Szopa, S., van der Werf, G. R., Voulgarakis, A., van Weele, M., Weiss, R. F., Williams, J. E., and Zeng, G.: Three decades of global methane sources and sinks, Nat. Geosci., 6, 813-823, https://doi.org/10.1038/ngeo1955, 2013.

le Texier, H., Solomon, S., and Garcia, R. R.: The role of molecular hydrogen and methane oxidation in the water vapour budget of the stratosphere, Q. J. Roy. Meteor. Soc., 114, 281-295, https://doi.org/10.1002/qj.49711448002, 1988.

Lossow, S., Steinwagner, J., Urban, J., Dupuy, E., Boone, C. D., Kellmann, S., Linden, A., Kiefer, M., Grabowski, U., Glatthor, N., Höpfner, M., Röckmann, T., Murtagh, D. P., Walker, K. A., Bernath, P. F., von Clarmann, T., and Stiller, G. P.: Comparison of HDO measurements from Envisat/MIPAS with observations by Odin/SMR and SCISAT/ACE-FTS, Atmos. Meas. Tech., 4, 1855-1874, https://doi.org/10.5194/amt-4-1855-2011, 2011.

Maxfield, P. J., Evershed, R. P., and Hornibrook, E. R. C.: Physical and Biological Controls on the In Situ Kinetic Isotope Effect Associated with Oxidation of Atmospheric $\mathrm{CH}_{4}$ in Mineral Soils, Environ. Sci. Technol., 42, 7824-7830, https://doi.org/10.1021/es800544q, 2008.

Monge-Sanz, B. M., Chipperfield, M. P., Untch, A., Morcrette, J.J., Rap, A., and Simmons, A. J.: On the uses of a new linear scheme for stratospheric methane in global models: water source, transport tracer and radiative forcing, Atmos. Chem. Phys., 13, 9641-9660, https://doi.org/10.5194/acp-13-9641-2013, 2013.

Monteil, G., Houweling, S., Dlugockenky, E. J., Maenhout, G., Vaughn, B. H., White, J. W. C., and Rockmann, T.: Interpreting methane variations in the past two decades using measurements of $\mathrm{CH}_{4}$ mixing ratio and isotopic composition, Atmos. Chem. Phys., 11, 9141-9153, https://doi.org/10.5194/acp11-9141-2011, 2011.

Mote, P.: The annual cycle of stratospheric water vapor in a general circulation model, J. Geophys. Res., 100, 7363-7379, https://doi.org/10.1029/94JD03301, 1995.

Nair, H., Summers, M. E., Miller, C. E., and Yung, Y. L.: Isotopic fractionation of methane in the martian atmosphere, ICARUS, 175, 32-35, https://doi.org/10.1016/j.icarus.2004.10.018, 2005.

Nickl, A.-L., Mertens, M., Roiger, A., Fix, A., Amediek, A., Fiehn, A., Gerbig, C., Galkowski, M., Kerkweg, A., Klausner, T., Eckl, M., and Jöckel, P.: Hindcasting and forecasting of regional methane from coal mine emissions in the Upper Silesian Coal Basin using the online nested global regional chemistryclimate model MECO(n) (MESSy v2.53), Geosci. Model Dev., 13, 1925-1943, https://doi.org/10.5194/gmd-13-1925-2020, 2020.

Nisbet, E. G., Dlugokencky, E. J., Manning, M. R., Lowry, D., Fisher, R. E., France, J. L., Michel, S. E., Miller, J. B., White, J. W. C., Vaughn, B., Bousquet, P., Pyle, J. A., Warwick, N. J., Cain, M., Brownlow, R., Zazzeri, G., Lanoisellé, M., Manning, A. C., Gloor, E., Worthy, D. E. J., Brunke, E.-G., Labuschangne, C., W., W. E., and Ganesan, A. L.: Rising atmospheric methane: 2007-2014 growth and isotopic shift, Global Biogeochem. Cy., 30, 1356-1370, https://doi.org/10.1002/2016GB00540, 2016.

Nixon, C. A., Temelso, B., Vinatier, S., Teanby, N. A., B'ezard, B., Achterberg, R. K., Mandt, K. E., Sherrill, C. D., Irwin, P. G. J., Jennings, D. E., Romani, P. N., Coustenis, A., and Flasar, F. M.:
Isotopic ratios in titan's methane: measurements and modeling, Astrophys. J., 749, 159, https://doi.org/10.1088/0004637X/749/2/159, 2012.

Olivier, J. and Janssens-Maenhout, G.: $\mathrm{CO}_{2}$ Emissions from Fuel Combustion 2012, chap. Part III, GreenhouseGas Emissions, p. 540, International Energy Agency, https://doi.org/10.1787/co2_fuel-2012-en, 2012.

Revell, L. E., Bodeker, G. E., Huck, P. E., Williamson, B. E., and Rozanov, E.: The sensitivity of stratospheric ozone changes through the 21 st century to $\mathrm{N}_{2} \mathrm{O}$ and $\mathrm{CH}_{4}$, Atmos. Chem. Phys., 12, 11309-11317, https://doi.org/10.5194/acp-12-113092012, 2012.

Rigby, M., Manning, A. J., and Prinn, R. G.: The value of highfrequency high-precision methane isotopologue measurements for source and sink estimation, J. Geophys. Res., 117, D12312, https://doi.org/10.1029/2011JD017384, 2012.

Röckmann, T., Brass, M., Borchers, R., and Engel, A.: The isotopic composition of methane in the stratosphere: high-altitude balloon sample measurements, Atmos. Chem. Phys., 11, 13287-13304, https://doi.org/10.5194/acp-11-13287-2011, 2011.

Roeckner, E., Brokopf, R., Esch, M., Giorgetta, M., Hagemann, S., Kornblueh, L., Manzini, E., Schlese, U., and Schulzweida, U.: Sensitivity of Simulated Climate to Horizontal and Vertical Resolution in the ECHAM5 Atmosphere Model, B. Am. Meteorol. Soc., 19, 3771-3791, 2006.

Sander, R., Kerkweg, A., Jöckel, P., and Lelieveld, J.: Technical note: The new comprehensive atmospheric chemistry module MECCA, Atmos. Chem. Phys., 5, 445-450, https://doi.org/10.5194/acp-5-445-2005, 2005.

Sander, R., Jöckel, P., Kirner, O., Kunert, A. T., Landgraf, J., and Pozzer, A.: The photolysis module JVAL-14, compatible with the MESSy standard, and the JVal PreProcessor (JVPP), Geosci. Model Dev., 7, 2653-2662, https://doi.org/10.5194/gmd-7-26532014, 2014.

Sander, S. P., Abbatt, J., Barker, J. R., Burkholder, J. B., Friedl, R. R., Golden, D. M., Huie, R. E., Kolb, C. E., Kurylo, M. J., Moortgat, G. K., Orkin, V. L., and Wine, P. H.: Chemical Kinetics and Photochemical Data for Use in Atmospheric Studies, Evaluation No. 17, JPL Publication 10-6, Jet Propulsion Laboratory, https://doi.org/10.1002/kin.550171010, 2011.

Saueressig, G., Bergamaschi, P., Crowley, J. N., and Fischer, H.: Carbon kinetic isotope effect in the reaction of $\mathrm{CH}_{4}$ with $\mathrm{Cl}$ atoms, Geophys. Res. Lett., 22, 1225-1228, 1995.

Saueressig, G., Bergamaschi, P., Crowley, J., and Fischer, H.: D/H kinetic isotope effect in the reaction $\mathrm{CH}_{4}+\mathrm{Cl}$, Geophys. Res. Lett., 23, 3619-3622, 1996.

Saueressig, G., Crowley, J. N., Bergamaschi, P., Brühl, C., Brenninkmeijer, C. A. M., and Fischer, H.: Carbon 13 and D kinetic isotope effects in the reactions of $\mathrm{CH}_{4}$ with $\mathrm{O}^{1}(\mathrm{D})$ and $\mathrm{OH}$ : New laboratory measurements and their implications for the isotopic composition of stratospheric methane, J. Geophys. Res., 106, 23127-23138, 2001.

Saunois, M., Bousquet, P., Poulter, B., Peregon, A., Ciais, P., Canadell, J. G., Dlugokencky, E. J., Etiope, G., Bastviken, D., Houweling, S., Janssens-Maenhout, G., Tubiello, F. N., Castaldi, S., Jackson, R. B., Alexe, M., Arora, V. K., Beerling, D. J., Bergamaschi, P., Blake, D. R., Brailsford, G., Brovkin, V., Bruhwiler, L., Crevoisier, C., Crill, P., Covey, K., Curry, C., Frankenberg, C., 
Gedney, N., Höglund-Isaksson, L., Ishizawa, M., Ito, A., Joos, F., Kim, H.-S., Kleinen, T., Krummel, P., Lamarque, J.-F., Langenfelds, R., Locatelli, R., Machida, T., Maksyutov, S., McDonald, K. C., Marshall, J., Melton, J. R., Morino, I., Naik, V., O’Doherty, S., Parmentier, F.-J. W., Patra, P. K., Peng, C., Peng, S., Peters, G. P., Pison, I., Prigent, C., Prinn, R., Ramonet, M., Riley, W. J., Saito, M., Santini, M., Schroeder, R., Simpson, I. J., Spahni, R., Steele, P., Takizawa, A., Thornton, B. F., Tian, H., Tohjima, Y., Viovy, N., Voulgarakis, A., van Weele, M., van der Werf, G. R., Weiss, R., Wiedinmyer, C., Wilton, D. J., Wiltshire, A., Worthy, D., Wunch, D., Xu, X., Yoshida, Y., Zhang, B., Zhang, Z., and Zhu, Q.: The global methane budget 2000-2012, Earth Syst. Sci. Data, 8, 697-751, https://doi.org/10.5194/essd-8-697-2016, 2016.

Schaefer, H., Fletcher, S. E. M., Veidt, C., Lassey, K. R., Brailsford, G. W., Bromley, T. M., Dlugokencky, E. J., Michel, S. E., Miller, J. B., Levin, I., Lowe, D. C., Martin, R. J., Vaughn, B. H., and White, J. W. C.: A 21st century shift from fossil-fuel to biogenic methane emissions indicated by ${ }^{13} \mathrm{CH}_{4}$, Science, 352, 8084, https://doi.org/10.1126/science.aad2705, 2016.

Snover, A. and Quay, P.: Hydrogen and carbon kinetic isotope effects during soil uptake of atmospheric methane and a temperate grassland, Global Biogeochem. Cy., 14, 25-39, 2000.

Solomon, S., Rosenlof, K. H., Portmann, R. W., Daniel, J. S., Davis, S. M., Sanford, T. J., and Plattner, G.-K.: Contributions of Stratospheric Water Vapor to Decadal Changes in the Rate of Global Warming, Science, 327, 1219-1223, https://doi.org/10.1126/science.1182488, 2010.

Steinwagner, J., Milz, M., von Clarmann, T., Glatthor, N., Grabowski, U., Höpfner, M., Stiller, G. P., and Röckmann, T.: HDO measurements with MIPAS, Atmos. Chem. Phys., 7, 26012615, https://doi.org/10.5194/acp-7-2601-2007, 2007.

Stenke, A. and Grewe, V.: Simulation of stratospheric water vapor trends: impact on stratospheric ozone chemistry, Atmos. Chem. Phys., 5, 1257-1272, https://doi.org/10.5194/acp-5-1257-2005, 2005.
Stolper, D., Sessions, A., Ferreira, A., Neto, E. S., Schimmelmann, A., Shusta, S., Valentine, D., and Eiler, J.: Combined C-D and D-D clumping in methane: Methods and preliminary results, Geochim. Cosmochim. Ac., 126, 169-191, https://doi.org/10.1016/j.gca.2013.10.045, 2014.

Tian, W., Chipperfield, M. P., and Lü, D.: Impact of increasing stratospheric water vapor on ozone depletion and temperature change, Adv. Atmos. Sci., 26, 423-437, https://doi.org/10.1007/s00376-009-0423-3, 2009.

Tost, H., Jöckel, P., Kerkweg, A., Sander, R., and Lelieveld, J.: Technical note: A new comprehensive SCAVenging submodel for global atmospheric chemistry modelling, Atmos. Chem. Phys., 6, 565-574, https://doi.org/10.5194/acp-6-565-2006, 2006.

Umezawa, T., Machida, T., Ishijima, K., Matsueda, H., Sawa, Y., Patra, P. K., Aoki, S., and Nakazawa, T.: Carbon and hydrogen isotopic ratios of atmospheric methane in the upper troposphere over the Western Pacific, Atmos. Chem. Phys., 12, 8095-8113, https://doi.org/10.5194/acp-12-8095-2012, 2012.

White, J., Vaughn, B., and Michel, S.: University of Colorado, Institute of Arctic and Alpine Research (INSTAAR), Stable Isotopic Composition of Atmospheric Methane $\left({ }^{2} \mathrm{H}\right)$ from the NOAA ESRL Carbon Cycle Cooperative Global Air Sampling Network, 2005-2009, Version: 2016-04-26, available at: ftp: //aftp.cmdl.noaa.gov/data/trace_gases/ch4h2/flask/ (last access: 18 January 2021), 2016.

White, J., Vaughn, B., and Michel, S.: University of Colorado, Institute of Arctic and Alpine Research (INSTAAR), Stable Isotopic Composition of Atmospheric Methane $\left({ }^{13} \mathrm{C}\right)$ from the NOAA ESRL Carbon Cycle Cooperative Global Air Sampling Network, 1998-2016, Version: 2018-01-31, ftp://aftp.cmdl.noaa.gov/data/ trace_gases/ch4c13/flask/ (last access: 18 January 2021), 2017.

Winterstein, F., Tanalski, F., Jöckel, P., Dameris, M., and Ponater, M.: Implication of strongly increased atmospheric methane concentrations for chemistryclimate connections, Atmos. Chem. Phys., 19, 7151-7163, https://doi.org/10.5194/acp19-7151-2019, 2019. 